Meta

Journal des traducteurs

Translators' Journal

\title{
Toward the Problem of Translating Grammatical Meanings
}

\section{Elena V. Padučeva}

Volume 37, numéro 1, mars 1992

La traduction en Russie : théorie et pratique / Translation in Russia: Theory and Practice

URI : https://id.erudit.org/iderudit/003777ar

DOI : https://doi.org/10.7202/003777ar

Aller au sommaire du numéro

Éditeur(s)

Les Presses de l'Université de Montréal

ISSN

0026-0452 (imprimé)

1492-1421 (numérique)

Découvrir la revue

Citer cet article

Padučeva, E. V. (1992). Toward the Problem of Translating Grammatical Meanings. Meta, 37(1), 113-126. https://doi.org/10.7202/003777ar

\section{Résumé de l'article}

À l'aide de l'étude de certains traits sémantiques telles la résultativité, la l'actualité, la multiplicité, etc., on établit les différences aspectuelles entre le verbe russe à la forme imperfective et à la forme perfective. 


\section{TOWARD THE PROBLEM OF TRANSLATING GRAMMATICAL MEANINGS: THE FACTUAL MEANING OF THE IMPERFECTIVE ASPECT IN RUSSIAN}

ELENA V. PADUC̆EVA Institute of Scientific and Technical Information (VINITI)

Moscow, USSR

Résumé

À l'aide de l'étude de certains traits sémantiques telles la résultativité, la factualité, la multiplicité, etc., on établit les différences aspectuelles entre le verbe russe à la forme imperfective et à la forme perfective.

The imperfective aspect (Ipfv) of the verb in Russian is opposed to the perfective aspect (Pfv) and is supposed to have several meanings (see Bondarko 1971; Maslov 1984; Apresjan 1980; Glovinskaja 1982) - progressive (aktual'no-dlitel'noe), i.e. He мещац̆ мне, я работаю ${ }_{\mathrm{Ipfv}}$ : Do not bother me, I am working; habitual (uzual' noe), e.g.

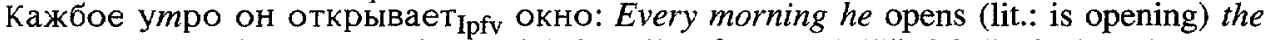
window; and a further meaning which is called factual (ob ̌̌šefaktičeskoe) and can be illustrated by the following examples:

(1) Вот на этой стене виселатрfу картина.

Here on this wall there hung (lit.: was hanging) a picture

(2) Я же Мам объяснял Ipfv!

Did not I explain, (lit.: was not I explaining) it to you?

- Объяснял ${ }_{\mathrm{Ipfv}}$, да не объяснил $\mathrm{pfv}$.

- You did explain, but not to the full. (lit.: You were explaining but you did not explain.)

(From Apresjan 1980)

(From Bondarko 1971)

The translation of the forms bearing the progressive or the habitual meaning into European languages poses no problem. Thus, the progressive meaning can be translated into English by the continuous forms (the term progressive meaning is used by A. Timberlake (1984) both for aktual'no-dlitel' noe in Russian and for continuous in English):

(3) Не мешай, я работаюIpfy.

(3') Do not bother me, I am working.

There are no special means of expressing the habitual meaning ${ }^{1}$, but it can be quite adequately translated by unmarked tense forms. In English these will be the forms of the present or the past indefinite.

As for the factual meaning, one can say that its translation is definitely a problem. Thus (1) can be translated into French in two ways: 
(1') Sur ce mur, il y avait/il y a eu eu un tableau.

In (2) a translator into French would be likely to explicate the idea of a futile attempt, though the Russian sentence Я же Мам объяснял ${ }_{\text {Ipfv }}$ does not express this meaning openly:

(2') - J'ai bien essayé de vous l'expliquer!

- Oui, mais vous n'y êtes pas arrivé.

It seems reasonable to suppose that several different meanings can be singled out within what is generally called the factual meaning. Consequently, a more fundamental semantic analysis of the forms bearing this meaning appears to be necessary in order to establish the possible equivalents in target languages.

Although the factual meaning of the Russian Imperfective aspect (Ipfv) has been much discussed in linguistic literature, it still remains fertile ground for those who are fond of complex linguistic problems.

The basic meaning among the factual meanings is the factual resultative. It is expressed by a verb in the Ipfv (Past tense) which denotes an action that has reached a natural limit; thus, Ты показывал showing) her this letter?) means approximately the same as Ты показал Pfv? (Did you show?) In connection with this meaning of the Ipfv the following question arises: why does the speaker who can use a verb in the Perfective aspect (Pfv), denoting a completed action, choose a verb in the Ipfv, normally devoid of this meaning? I.e. why does he say показывал words, what are the semantic differences between the verb in the Ipfv and the matching verb in the Pfv?

The answer to this question should follow from the comparison between the semantic interpretations of the Pfv in its basic meaning and the resultative Ipfv. The interpretation of the Pfv causes no problems, but there is no complete and satisfactory interpretation for the resultative meaning of the Ipf $\mathrm{v}^{2}$.

The semantic interpretation of the Ipfv to be given further is not intended to be complete for the factual meaning - it is purely functional, i.e., this interpretation must perform the following functions:

1. It must make clear the conditions under which it is possible to use the Ipfv in its factual meaning, resultative or otherwise. E.g. it must explain why we cannot say $*$ Kmo ронял Ipfv? кошелек?: Who dropped (lit.: was dropping) the purse? in the Ipfv (When we are talking of a purse which has just been dropped) or why Ты решал Iрfv задачу? (Did you solve (lit.: were you solving) the problem? does not mean Ты решил you solve?) i.e., does not have a resultative meaning.

2. It must determine the lexical, syntactic and pragmatic context which is needed for the verb in the Ipfv to acquire a resultative meaning: ideally, all the conditions which are favourable or which, conversely, make the realization of the factual resultative meaning impossible (see Glovinskaja 1982: 132-144) must follow from one or another component of this semantic interpretation.

3. It must ensure a possibility of semantic comparison between Ipfv and Pfv; i.e., all the semantic differences between the factual resultative and its aspectual match Pfy must either consist in the differences between some of the components of their semantic interpretation or must be the natural semantic entailments of these differences.

4. Finally, it must serve as a convenient basis for providing adequate equivalents for the Russian aspectual form in the target languages. 
The factual resultative is opposed to non-resultative (neresultativnoe), e.g. Ты сегодня решал and non-telic (nepredel'noe), e.g. Вот на этой стене висела ${ }_{\mathrm{Ipfv}}$ картина. Here on this wall there hung (lit:: was hanging) a picture. The so-called meaning of factual twoway action (dvunapravlennoe) ( $\mathrm{K}$ mебе кmо-то приходи $\boldsymbol{I}_{\mathrm{pfv}} \supset$ 'и ушел' - Someone came (lit.: was coming) to see you $\supset$ 'and left') is according to Glovinskaja (1982: 123) a variation of the resultative, as приходиол ${ }_{\text {Ipfv }} \supset$ 'пришел' as to the fact whether the action has indeed reached the natural limit or not we shall consider just as an ambiguity (caused e.g. by insufficiency of the context) and not as a separate meaning. Cf.: Кто строил Ipfv этот завод? Who built (lit.: was building) this plant? (The construction of the plant may never have been completed).

The question of the presence or absence of the resultative presentation can be put only in respect to such a verb in the Ipfv that has a matching verb in the Pfv: only the meaning of the verb in the Pfv fixes the result, i.e., the resultant final state of the situation which can be either reached or not. Only a matching verb in the Ipfy can basically allow for a resultative interpretation. Thus, for the verb искатъ Ipfv (to be looking for), which has no match in the Pfv, in the phrase Вы искали Ipfv коменданma? Did you look (lit.: were you looking) for the superintendent? (Glovinskaja 1982: 124) the idea that the action has reached a natural limit cannot be expressed same as it cannot be expressed by the verb Bucem ${ }^{\mathrm{b}} \mathrm{Ipfv}$ (to be hanging); the factual meaning of the Ipfv we call non-telic. The same goes for сmреляться ${ }_{\mathrm{Ipfv}}$ (to shoot oneself), браться на дуели a duel), подстрекать Ipfv (to instigate), etc. Verbs in the Ipfv having no match in the Pfv even if they have an obvious resultative meaning, e.g. the verb ви деmbIpfv (watche.g. a film), analyzed by Apresjan (1980), will be outside the scope of our interest, because our final aim is to establish the difference between the resultative Ipfy and the matching Pfv.

It should be noted that the verb in the Ipfv forms an aspectual pair with Pfv if it can denote a multiple realization of the situation denoted by the verb in the Pfv (see

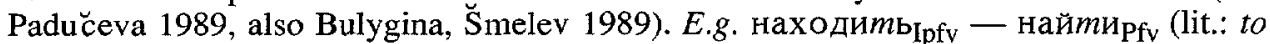
be finding - to find) is an aspectual pair, whereas заподозритьрfv подозревать $\mathrm{b}_{\mathrm{Ipf}}$ (to start suspecting - to be suspecting) is not: побозревать cannot mean "to start suspecting many times." In the same way the following verbs cannot make an aspectual pair either: умоля to have besought), уверяmь ${ }_{\mathrm{Ipfv}}$ - увериmь ${ }_{\mathrm{Pfv}}$ (to be assuring - to have assured). Умолять Ipfv does not mean 'умолитьрfv many times', уверяmь Ipfv - "make somebody assured many times." Nor does настаивать Ipfy (to be insisting) mean 'неоднократно настоять' ${ }_{\text {Pfv }}$ (to have had one's own way many times).

Further we shall consider a number of the semantic features which were offered in a few linguistic papers as components of the factual resultative meaning. We shall show that many of these features are realized only in part of the usages, but in spite of that their combination forms this meaning as such.

\section{RESULTATIVITY}

The component "Resultativity": "the situation (denoted by the verb) has reached its natural internal limit and at a certain moment its resultant state has set in." For verbs of achievement like нахобц $\mathrm{b}_{\mathrm{bpfv}}$ (to find), which do not have the process phase, i.e., which do not denote a process aimed at reaching a natural limit, "Resultativity" is just the setting in of the resultant state. 
The component "Resultativity" is, naturally, common for all the resultative usages of the Ipfv. However, the status of this component in different contexts is different. Thus, in the phrase

(4) Где апельсины покупал Ipfv $_{\text {? }}$ ?

Where did you buy (lit.: were you buying) the oranges?

the "resultativity", i.e., the idea that the limit has been reached is an implicature arising under the influence of the context which, more likely than not, cannot be included into the semantic presentation of the sentence (see Padučeva 1986). Cf. The semantic presentation of (5).

(5) К тебе кто-то приходил Ipfv.

Someone came (lit.: was coming) to see you.

where the component "came (and left)" is definitely present.

There are a number of semantic or lexical classes of verbs for which the resultative interpretation of Ipfv is in the past tense the only possible option and in which, obviously, the component "resultativity" is included into the semantic presentation of the sentence. These verbs can be divided into two groups.

1. Verbs in the Ipfv which do not allow for a progressive (and, in general, a synchronic non-iterative) meaning of the Ipfv in Russian:

а) видеться (see someone), покушаться (make an attempt - e.g. on someone's life), останавливаться (stop - e.g. in a hotel), отлучаться (leave), собцраться (in the meaning of "get together" as for a meeting), посещтв (visit) (Cf.: Он сейчас посещает родственников (lit.: he is now visiting his relatives), etc.

b) случаться (happen), сталкиваться (come upon), встречаться (meet), бывать (frequent); приходить (come), находить (find), приносить (bring), приезжать (arrive), еtс.; вызубривать (learn by heart), высушивать (make dry), сьедать (eat up), выпивать (drink up), устаревать (become dated), ослабевать (wear off), etc. Cf.: ${ }^{*}$ Мне (в данный момент) встречается Ipfv девочка с ведром - I (at the present moment) meet (lit.: am meeting) a girl with a bucket.

2. Verbs which have the following semantic property: Ipfv Pres $\supset$ "Pfv Past" (this class was singled out by Maslov 1948):

a) verbs of "immediate effect": касаться (touch lightly), гладить (stroke), обнимать (hug), mрогаmь (touch), щупать (feel), etc. (see Glovinskaja 1982: 131); thus, ксается ${ }_{\text {Ipfv }}$ (is touching) $\supset$ 'коснулся'Pfv (has touched);

b) verbs which do not allow for a futile attempt: пытаться (attempt), стараться (try to), пробовать (venture), etc. Thus пыmaemся (is trying) つ 'попытался' (has tried).

c) the verbs of informing (see Glovinskaja 1982: 131): просиmь (ask), предупреждать (warn), звать (call), приглашаmь (invite), paзрешать (allow), посылать (send), звонить (call), говорить (speak), mребовать (demand), советовать (advise), обещать (promise), благодарить (thank), клясться (swear) and so forth, which in the third person present tense can denote a state, accompanying the speech act. E.g. OH обещаe $m_{\mathrm{Ipfv}}$ (he is promising) $\supset \mathrm{OH}^{\circ}$ пообещал'pfv (he has promised); i.e. он обещаеm $\mathrm{Ipfv}$ presupposes 'пообешал'Pfv. These verbs have the property mentioned above only in the third person: in the first person they are used performatively. 


\section{FACTUALITY}

The component "Factuality": Ipfv in the factual meaning serves to assert a fact, i.e. in affirmative sentences with a verb in the Ipfv factual the attention is focussed on the fact that the situation, denoted by the verb, has taken place (and in negative sentence on the fact that the situation has not taken place). The sense of the question with a verb in the Ipfv factual is to find out whether the situation has taken place or not.

It is due to this component that the term Ipfv factual is used for the meaning of the Ipfv discussed here: this component is considered as basic for the Ipfv factual by Rassudova (1968: 17) and Bondarko (1971: 85). Thus, Rassudova (1968) stresses the connection between the Ipfv factual and the illocutionary attitude of the speaker which is manifest in the main stress being on the opposition "was/was not" (bylo/ ne bylo). Forsyth (1970: 82) translates the expression "констатация Факта действия", used in Russian studies to describe the function of the Ipfv factual like this: a report or declaration that the action did occur (cf. also Chaput 1990).

The main sentence stress placement on the verb (usually it is contrastive stress) is in this case a means of expressing factuality. Indeed, in the paradigmatic examples of Ipfv factual the main sentence stress falls on the verb:

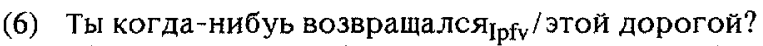
Did you ever return (lit.: were you ever returning)/by this road?

(7) я тебя предупреждал ${ }_{\mathrm{Ipfv}} \backslash$ I warned (lit.: was warning) \you.

Sentence (non-contrastive) stress on one of the arguments does not, however, deprive the utterance of the status of asserting the fact:

(8) Этот Фильм показывали Ipfv по телевизору \} This film was shown (lit.: was being shown) on TV

The placement of the stress on the verb in this case would only put the sentence in the polemic context:

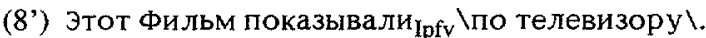
This film was shown \on TV.

Further we shall show that the concept of fact does not play a merely terminological role in the definition of the factual meaning (see \$4).

Sentence stress in Russian can be in itself a factor, determining the use of the verb in the factual meaning rather than in the progressive one (see Glovinskaja 1982: 141), e.g.:

(9) а. Я смотрела $\mathrm{Ipfv}$ этот дурацкий Фильм

I watched (lit.: was watching) this stupid film \. (progressive interpretation possible)

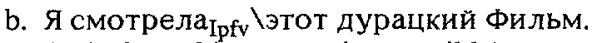
(only factual interpretation possible)

It would seem that the component "Factuality" can be included in the interpretation of the Ipfv factuals, however, the verbs in the Ipfv in the examples (10a) and (10b) for instance, cannot be interpreted as denoting a fact - the main stress is here on the adverbial and the fact that the situation denoted by the verb took place is a presupposition:

(10) а. Операцию делали Ipfv ему в Москвеl He was operated on (lit.: was being oparated on) in Moscow $\backslash$ 
b. В этой портерной я написал... первое любовное письмо к Варе. Писал Ipfv карандашом ᄂ

In this porternaya I wrote... my first love letter to Varya. I wrote it (lit.: was writing it) with a pencil $\backslash$ (From Forsyth 1970)

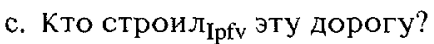

Who built (lit.: was building) this road?

A general question is a question about a fact, see (11a); however in a special question as well as in a sentence with contrastive stress on one of the arguments, the fact that the situation took place is presupposed, cf. (11b):

(11) а. Ты выносил Ipfv \мусор?

$\mathrm{Did} /$ you take out (lit.: were you taking out) the garbage? (a question about fact)

b. Ты / выносил Ipfv? мусор?

Was it you who took out (lit.: was taking out) the garbage? (A question about the agent of the action; the fact of the action is presupposed)

Thus, the component "Factuality," while it is definitely relevant, is not common for all the usages of the Ipfv usually assumed to be factual.

Here are some more examples where the stress placement on the verb is relevant for the interpretation:

(12) а. Я открывал

I did \open (lit:: was \opening) the window. (only factual presentation possible)

b. Я открывал

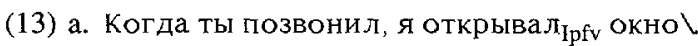
When you called I was opening the window

b. * Когда ты позвонил, я открывал ${ }_{\text {Ipfy }} \backslash$ окно.

(14) а. Вода доходила Ipfv \ему до колен. The water reached (lit.: was reaching) up to his knees. (factual meaning)

b. Вода доходила ${ }_{\text {Ipfv }}$ ему до колен\ (progressive)

(15) а. Иван возглавлял Ipfv \отдел кадров. Ivan headed $\backslash$ (lit.: was heading) the Staff department. (factual)

b. Иван возглавлял

Also relevant for the interpretation is the word order. Cf.:

(16) "Капитанскую дочку" я читал Ipfy

"Kapitanskaja docka"I have read $\backslash$ (lit.: was reading).

Анкету я заполня Ipfv $_{\text {. }}$

The form I have filled out $\backslash($ lit.: was filling out $)$.

\section{MULTIPLICITY}

The component "Multiplicity": "the situation (denoted by the verb) took place at least once or more than once": In other words, the Ipfv factual usually presents situations with indefinite multiplicity (see Bondarko 1971: 84). Cf.:

(17) Мне случалось Ipfv потерять паспорт.

I happened (lit.: was happening) to lose a passport (= "at least once I lost one"); 


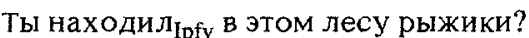

Did you ever find (lit.: were you ever finding mushrooms in this forest? (= "have you found at least once?");

Я ши $\Omega_{\mathrm{Ipfv}}$ такие куртки.

I made (lit.: was making) such jackets (= "made at least one").

However, the factual meaning is often present in the context of an utterance, denoting a single situation as in (18) or in (10);

(18) Вы обедалйрf?

Did you have (lit.: were you having) dinner? (="today")

Cf. the contrast - multiplicity in (19a) and a single situation in (19b):

(19) а. Сергей вешал Ipfv \эту карту. <Он знает, как это делается>.

Sergei put $\backslash$ (lit.: was putting) this map on the wall. $<$ He knows how it is done. $>$

b. Сергей вешал Ipfv $\backslash$ тогда карту. <я точно помню>.

Sergei did put (lit.: was putting) the map on the wall then. <I remember it exactly.>

It is possible to say that as a rule the information about the situation being single and not multiple is not included in the meaning of the Ipfv factual but is determined by some element of the context in which it occurs. Thus, in (18) the presentation of the situation as single is achieved on the pragmatic level - it follows from the fact that we dine once a day and the question refers to a particular day when the conversation is taking place. In (19) the singularity of the situation is expressed by the adverbial modifier of time: тогда (then = "at what time"). In (10) it is pointed to by the concrete referential status of the object: you cannot build the same road or write the same letter many times.

Multiplicity of the situation as well as factuality can be an important factor determining the interpretation of a verb in the Ipfv as resultative; i.e. the explicit multiplicity has as its consequence the definitely resultative interpretation of the Ipfv:

(20) а. Петя решал $\pi_{\text {Ipfv }} \backslash$ такие задаци.

Peter solved (lit.: was solving) such problems (multiple situation, resultative interpretation).

b. Петя решал

Peter tried to solve (lit.: was solving) the problem (single situation, non-resultative interpretation).

Normally one and the same problem cannot be solved several times; it seems natural that just for this reason $(20 \mathrm{~b})$ does not allow for a resultative interpretation even under sentence stress, i.e. when the "Factuality" component is present, which in itself favours a resultative interpretation. If, however, a resultative interpretation does appear in this case, it is only because it is still possible to solve the same problem several times.

The context of multiplicity, i.e. the potential possibility of a multiple realization of the situation, turns out to be an important condition making possible the resultative interpretation of the Ipfv even when the action in question is single; in other words in some contexts it is multiplicity that brings forth the component "Resultativity." $\mathrm{Cf}$. an example bearing out the connection between the resultative interpretation of the Ipfv factual and the potential multiplicity of the situation:

(21) а. А тыква/превращалась Ірfv в спектакле "Эолушка" в карету And the pumpkin/turned (lit.: was turning) in the play "Cinderella" into a carriag $\backslash$ (From Glovinskaja 1982: 129) 
b. А дом/превращался \}

And the house/was turning into a heap of rubble \.

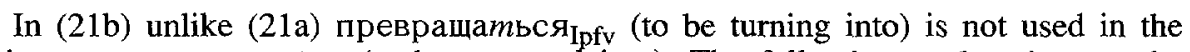
meaning 'превратиться' suggested. The only noticeable difference between (21a) and (21b) is that in (21a) we are told about a regular and, consequently, a reversible transformation, which happens several times during each performance, and (21b) describes a transformation which can take place only once. Hence the most natural interpretation for (21b) is progressive. Cf. another example:

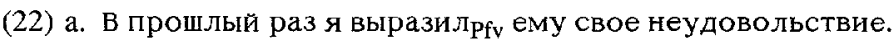
Last time I expressed my displeasure to him.

b. Я сейчас вырази $\pi_{\mathrm{Pfv}}$ ему свое неудовольствие. I expressed my displeasure to him now.

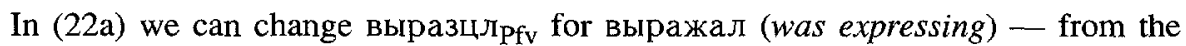
point of view of reaching the limit these two forms are of equal value in Russian, but выражал Ipfy contrasts the situation mentioned with some other situations and, consequently, stresses the potential multiplicity of the situation when displeasure is expressed. However, if we change выразц (Pfv) for выражал (Ipfv) in (22b), the Ipfv would be interpreted as progressive (synchronic with the point of reference, set by the adverbial modifier cец̆час (now): "was at a given moment in the process of expressing").

The connection between resultativity and multiplicity, which comes through in the combinability, has an obvious semantic foundation: if a verb in the Ipfv signifies a multiple realization of the situation denoted by a verb in the Pfv, then "one quantum" of this process is a situation that has reached a natural limit.

Explicit means of expressing a single situation are equivalent to multiplicity for they presuppose the potential multiplicity of the situation. Rassudova $(1968: 17,26)$ states that однажды (once), один раз create a favourable context for the factual

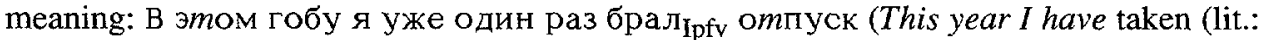
was taking) a holiday once.

It should be noted that the multiplicity of the situation means that the situation can be multiply reproduced in time - with an unchanging set of participants, - i.e. a multiple situation is a situation distributed in time. Multiplicity however should be distinguished from distributivity: distributivity is the distribution of the situation over a certain class of participants. The meaning of a limit being reached ("Resultativity") is brought forth both by multiplicity and by distributivity (the idea of more-than-oneness in both cases):

(23) а. Я много раз находил Ipfv клад.

I found (lit: was finding) treasures many times. (Multiplicity)

b. Многие смельчаки находили Ipfv там себе могилу.

Many brave men found (lit.: were finding) their death there. (distribution over the set of participants)

The difference between a multiple and a distributive situation is however essential, for multiplicity (in all the cases excluding habituality) requires a retrospective point of reference and, consequently, adds to the factual meaning (see \$6). Distributivity, on the other hand, is indifferent to the point of reference, so in the context of distributivity the component "Resultativity" is not tied with the factual meaning; thus in (24b) the 
resultative interpretation exists in the Present tense, although not in the factual usage of the Ipfv, for in the Present the factual Ipfv is impossible:

(24) a. В этой стране люди старились Ipfv, Past К сорока годам. In that country people got old (lit.: were getting old) by forty.

b. В этой стране люди рано старятся Ipfv, Present In that country people get old (lit.: are getting old) early.

\section{ALIENATION OF THE ACTION FROM THE MOMENT OF SPEECH}

The component: "Alienation of the action from the moment of speech": "the resultant state (or result) has not been preserved at the moment of speech or at any other point of reference." The term "razobšsennost" (alienation) belongs to A.V. Isačenko; cf. also Rassudova (1968: 22). Cf. the typical contexts for the Ipfv (as different from the Pfv):

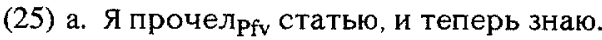
I have read the article and now I know.

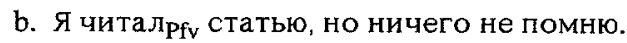

$I$ read (lit.: was reading) the article, but I remember nothing.

Glovinskaja (1982: 118) gives a weaker interpretation of the component "Alienation of the action from the moment of speech": "it is not known, whether the result has been preserved." In such interpretation the component need not be included in the interpretation of the Ipfv factual, because this meaning of the Ipfv follows from the opposition of form in the Ipfv to the form in the Pfv, the latter having the perfectivity, i.e. the retainment of the result at the moment of speech as one of the most obvious components of its meaning (see Padučeva 1989).

The stronger interpretation given at the beginning of this paragraph is true for such usages of the Ipfv resultative that also possess the components "Factuality" and "Multiplicity." "Alienation" treated like that is then a component of the Ipfv factual and not a component which the Ipfv has by default. Cf.:

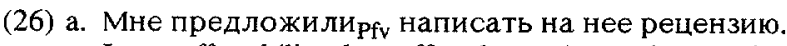

I was offered (lit.: they offered to me) to write a review of her paper.

b. Мне предлагали Ipfy написать на нее рецензию.

I was offered (lit.: they were offering to me) to write a review of her paper.

(26b) is more suitable in a situation when I have already refused or when the time for a positive answer has expired. (26a) is natural when I am still thinking whether to agree or not. Here are a few other examples:

$$
\begin{aligned}
& \text { (27) - От кого письмо? - Не знаю, мне } \\
& \text { няня передаларf } \\
& \text { *передавала }{ }_{\text {Ipfv }} \\
& \text { (it to me) } \\
& \text { * was giving }
\end{aligned}
$$

(28) Когда же выпал

$$
\text { *выпадал }
$$


When did the snow fall?

* was the snow falling?

In (27), (28) the inappropriateness of the Ipfv is caused by the obvious retainment of the resultant state at the moment of speech.

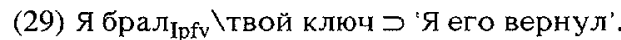

I took (lit.: was taking) your key $\supset$ "I returned it."

я открывал Ipf \окно つ 'Окно сейчас закрыто'.

I opened (lit.: was opening) the window $\supset$ "The window is closed now."

The component "Alienation" explains the semantic mechanism of the meaning of two-way action: if in the context of a verb denoting an action, for which the action in the opposite direction (or a reverse action) is possible, the resultant state has not been preserved, it follows that it was removed by a reverse action. Thus, from открывал Ipfv (opened, was opening) it follows that 'потом закрыл' (then closed) or 'потом закрылось' (then it closed).

Besides that the semantic component "Alienation" unites the factual resultative with the non-telic; the only semantic component within the factual non-telic is the following: "a state or a non-telic process is not taking place at the moment of speech." Cf.: Вот на этой стене висела ${ }_{\text {Ipfv }}$ картина - Here on this wall there hung (lit.: was hanging) a picture, Я вас люби $Л_{\text {Ipfv }} I$ loved (lit.: was loving) you. The resultant state of the situation is thought of as its integral part.

There is a specific class of the factual usages of the Ipfv which as it might seem testify against the inclusion of the component "Alienation" into this meaning:

(30) а. - Хочешь борща? - Спасибо, я обедал ${ }_{\mathrm{Ipfv}}$.

- Would you like some boršc - Thanks, I have had (lit.: was having) dinner.

b. - Пойдем со мной в кино! — Я смотрел

- Let us go to the cinema! - I have seen (lit.: was watching) this film.

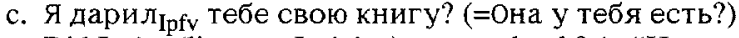

Did I give (lit.: was I giving) you my book? (= "Have you got it?)

In all these cases, however, it is not the retainment of the resultant state that is spoken about, but the consequences of the fact that the corresponding action was performed (cf. Bondarko 1972: 88). Thus, in (31) the state of possessing is presented by the speaker as a consequence, following from the fact of giving. Cf. the same in (32):

(31) Он дари

He gave (lit.: was giving) me his book. $\supset$ "I have got it."

(32) Должна быть моя карточка. Я записывался ${ }_{\mathrm{Ipfv}}$

There should be my registration card. I got (lit.: was getting) registered.

(From Lejnonen 1982)

In some contexts the information about the retainment of the resultant state of the process and the information about the consequences of the fact that the process took place are indistinguishable from each other:

(33) Почему ты не пришел? Мы же с тобой условилисьрf / уславливались! Ipfv Why did not you come? We arranged/(lit.: were arranging) to meet.

In both cases the agreement is still in force (the force of the agreement is retained): in the first case because the resultant state still lasts, in the second - because of the fact of its conclusion, so the meanings of the Pfv and the Ipfv are barely distinguishable. 
Here are a few more examples of another type which on the face of it testify against the proposed treatment of the component "Alienation":

(34) Ты брал Ipfy со стола ключи?

Did you take (lit.: were you taking) the keys from the table? (When the keys are not on the table)

(35) Ты переставлял Ipfv мои книги? Did you move (lit.: were moving) my books? (When the books have been moved)

(34) can be explained as follows: it is not брал/не брал (took/did not take) that are contrasted here, but You took the keys is contrasted with Something else happened to the keys. I.e. the state that the speaker sees may be the result not of the given action only, but for some other actions, so that we cannot say that the utterance was made just in the context of the retained resultant state of the action denoted by the Pfv verb взять ( $t o$ take). (35) is obviously uttered in the absence of complete assurance that the books have been indeed moved. Otherwise it would be more natural to say Ты переставлял Ipfv моц книги? Was it you who moved my books?

So if the components "Factuality" and "Multiplicity" are present the meaning of factual resultative includes the component "Alienation."

At the same time in the absence of these components the Ipfv is freely used in the context of retained resultant state, see (10).

\section{INDEFINITENESS OF THE TIME OF COMPLETION}

The component "Indefiniteness of the time of completion": "The time of the completion of the action and the setting in of the resultant state is indefinite" (see Glovinskaja 1982: 12).

This component of the Ipfv factual is obviously opposed to the Pfv, one of whose components is "the definiteness of the time of completion." Indeed, in a sentence where the Pfv verb has a point-of-time adverbial, the adverbial denotes the time of the completion of the action. In the absence of the adverbial the Pfv presupposes that the completion of the action coincides with the moment of speech or with some other point of reference, set in the context. This is well accounted for by the semantic interpretation of the Pfv in which the fact of completion is supposed to be the main assertion in its semantic layout.

For the Ipfv factual the typical usage is without the adverbial modifier of time or with an adverbial modifier which explicitly states temporal indefiniteness like когданибудь (ever), как-то (once). Under these conditions the time the resultant state sets in is a certain (indefinite) moment preceding the point of reference:

(36) Ты читал $\mathrm{Ipfv}$ "Капитанскую дочку?"

Lit.: were you ever reading "Kapitanskaja dočka?" (= "Have you ever read?")

A verb in the Ipfv factual allows for an indicator of a time period (the term is from Padučeva 1988) which sets a fairly wide time interval for the situation and does not eliminate the indefiniteness of the time of completion - in this case, in fact, it is not completion of the process that is localized, but the process itself:

(37) я разбиралIрfv одно похожее дело в прошлом году. I investigated (lit.: was investigating) a similar case last year.

(From Lejnonen 1982) 
Thus, we have sufficient reason to include "Indefiniteness of the time completion" as one of the components into the factual meaning of the Ipfv. The only exception here are the verbs of two-way action for which the moment of the resultant state setting in can be given quite definitely:

(38) Он когда-нибудь возвращался ${ }_{\text {Ipfv }}$ в полночь?

Did he ever return (lit.: was he ever returning) at midnight?

Почтальон приходилірfv в 8 утра.

The postman came (lit.: was coming) at eight in the morning.

Мы встречались Ipfy с ней в два часа.

We met (lit.: were meeting) with her at two o'clock.

Two-way verbs also allow for an adverbial setting the period of time during which the resultant state lasted (it did not last after a certain point): Иван приходил Ipfv на полчаыа (Ivan came (lit.: was coming) for half an hour); ОН просыпался Iрfv Минут на пять (Hе woke up (lit.: was waking up) for about five minutes).

The semantic interaction of the Ipfv factual with a time adverbial is one of the consequences of the "communicative structure" of its semantic layout: the setting in of the resultant state (result) is not in the focus here, it is not the main assertion, as it is in the Pfv. Hence the fact that not only the time adverbial but all the other adverbial modifiers which are allowed in the context of the Ipfv factual refer to the process, i.e. to the activity and not to the result:

(39) Он приходил Ipfv, чтобы проститься.

He came (lit.: was coming) to say good-bye.

It is the process that is directed towards the given aim and not its completion: in the interpretation of this sentence the aim should be related to шел ${ }_{\mathrm{Ipfv}}$ (was going) and not to прише ${ }_{\mathrm{Pfv}}$ (has come); он шел, чтобы проститься (lit.: he was coming to say goodbye).

The constraint on the combinability illustrated in (40), taken from Rassudova (1968), also bears out the fact that the component "Indefiniteness of the time of completion" in the meaning of the Ipfv factual is a consequence of the non-assertive character of the resultative component:

(40) а. Ты, наконец, передалрғу ему мою книгу? Have you given him my book yet?

b. * Ты, наконец, передавал Iрfv ему мою книгу? Lit.: were you giving him my book yet?

The basic context for Ipfv factual is with the adverbial modifier of time absent. Only in such contexts the component "Factuality" can be present, which requires the placement of sentence stress on the verb. In a sentence with a rhematic adverbial of time the fact that the action was performed will form the presupposition and thematic adverbial of time does not allow for factual meaning because it sets the synchronic point of reference (see $\$ 6$ ).

"Indefiniteness of the time of completion" is a component which the Ipfv factual always has in the absence of an adverbial of time (Мой дядя восходил Ipfv на Эверест - My uncle climbed (lit.: was climbing) Everest). The way of semantic interaction with adverbials of time, like with many other semantic operators, is determined by the communicative status of the component "Resultativity" (nonassertive). 


\section{RETROSPECTIVE POINT OF REFERENCE}

The component "Retrospective point of reference" (or the retrospective position of the observer; for the notion of observer see Apresjan 1986) is the only component that is really common for all the factual meanings of the Ipfv - both resultative and nonresultative, including non-telic (see Padučeva 1986), - unlike the progressive meaning which has a synchronic point of reference. It was stated most clearly by Wierzbicka (1967).

Besides the factual meanings of the Ipfv the retrospective point of reference is present only in durative meanings (Я гуля ${ }_{\mathrm{Ipfv}}$ с двух до $\mathrm{mpex}-I$ walked from two to three (lit.: was walking) and definite multiple meaning - Maslov's (1984) term ( 9 стучал Iрfv however are always marked by an explicit adverbial of duration or multiplicity. Thus the component "Retrospectivity" is the only one really characteristic of the factual meaning of the Ipfv. The hesitations, whether a certain Ipfv usage should be interpreted as factual or as progressive, arise when the position of the observer as to time (or, in other words, the temporal point of reference) is not clear; cf. the ambiguity of the following sentence:

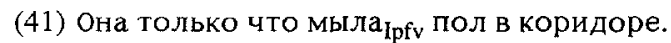

She was washing the floor in the corridor just a moment ago.

in the context Ты не видел машу? (Have you seen Maša?) (41) will be interpreted as having a synchronic point of reference and as used in the progressive meaning; however, in the context зачем ты моешь пол? (What for are you washing the floor?) (41) will be seen as viewed retrospectively (having a retrospective point of reference) and used in the factual meaning of the Ipfv. Cf. also (10) where with the transition from one mention of the situation of writing to another the point of reference may change.

Thus, our analysis shows that the resultative usages of the Ipfv do not form one meaning but several different meanings. The meaning which includes all the six components discussed above may be called existential (Мой дядя восходил Ipfv на Эверест - My uncle climbed (lit.: was climbing Everest). On the other side of the scale is the actional (akcional'noe) meaning (Где апельсины покупали ${ }_{\mathrm{Ipfv}}-$ Where did you buy the oranges (lit.: where were you buying?) which does not include any of the characteristic components of the factual meaning, except the retrospective point of reference. This complexity of the factual meaning - the presence of many different components - accounts for the difficulties arising in the process of translation: in different contexts different components come to the fore, which requires different equivalents in different cases.

Notes

1. As Jakobson (1955) - one of the best specialists in the theory of translation - says, the absence in a certain language of direct equivalents for expressing certain meanings does not hinder the process of translation so much. It is much more difficult for the translator to preserve the ambiguity if it is for one or another reason required by the original.

2. About the description of grammatical meanings by means of lexicographic definitions see Apresjan (1980). The method of lexicographic definitions was applied to slavonic aspect for the first time by Wierzbicka (1967). Definitions of the progressive meaning of the Ipfv (different semantic classes of verbs) were given by Glovinskaja (1982). She also formulated some of the components of the Ipfv factual, see further.

\section{BIBLIOGRAPHY}

APRESJAN, Yu.D. (1980): "Tipy informatsii dl'a poverhnostno-semantičeskogo komponents model'i smysl $\longrightarrow$ tekst" " (Types of Information for the Surface-Semantic Component of the Model "Sense $\longrightarrow$ Text"), Wiener Slawistische Almanach, Sbd.1, Wien. 
APRESJAN, Yu.D. (1986): "Deiksis v leksike i grammatike i naivnaja model' mira" (Deiksis in Lexics and Grammar and the Naive Model of the World), Semiotika i informatika, Vsesojusnyj Institut Naučnoj i Tehni českoj Informacii, Vypusk 28.

BONDARKO, A.V. (1971): Vid i vrem'a russkogo glagola (Aspect and Tense of the Russian Verb), Moscow, Prosvescenie.

BULYGINA, T.V., A.D.ŠMELEV (1989): "Mental'nye predikaty v aspekte aspektologii" (Mental Predicates from the Point of View of Aspectology), Znanije i mnenije. Problemy intensional'nyh i grammatičeskih kontekstov, Moscow, Nauka, pp. 31-54.

CHAPUT, P.R. (1990): "Temporal and Semantic Factors Affecting Aspect Choice in Questions," Slavic Aspect, Ed. Thelin N., John Benjamins Publ.

FORSYTH, J. (1970): A Grammar of Aspect, Cambridge, CUP

GLOVINSKAJA, M.Ja. (1982): Semantičeskie tipy vidovyh protivopostavlenij russkogo Glagola (Semantic Types of Aspectual Oppositions of the Russian Verb), Moscow, Nauka.

JACOBSON, R. (1955): "On Linguistic Aspects of Translation," On Translation, Ed. Brower R.A., Cambridge, Mass.

LEJNONEN, M. (1982): Russian Aspect, "Temporal'naja Lokalizacija" and Definite/Indefinite, Helsinki, Neuvostoliitto-Instituutin vuosikizja, V. 27.

MASLOV, Yu.S. (1984): Očerki po aspektologii (A Glimpse of Aspectology), Leningrad, Leningrad State University.

PADUČEVA, E.V. (1986): "Semantika vida i točka otšceta" (The Semantic of Aspect and the Point of Reference), Izvestija AN SSSR, Serija Literatury i Jazyka, no. 5.

PADUČEVA, E.V. (1988): "K semantičeskoj klassifikacii vremennyh determinantov predlošenija" (To the Semantic Classification of Time Adverbials in a Sentence), Jazyk: sistema i funkcionirovanie, Moscow, Nauka.

PADUC̆EVA, E.V. (1989): "K poiskam invarianta v snatčenii glagol'nogo vida" (Looking for the Invariant in the Meaning of Verbal Aspect), Naučno-tehničeskaja informatcija, serija 2, no. 12, pp. 24-31.

RASSUDOVA, O.P. (1968): Upotreblenije vidov glagola v russkom jazyke (The Use of Different Aspectual Forms of the Verb in Russian), Moscow, Izdatel'stvo MGU.

TIMBERLAKE, A. (1984): "The Temporal Schemata of Russian Predicates," Issues in Russian Morphosyntax, Columbus, Ohio, Slavic Publishers.

WIERZBICKA, A. (1967): "On the Semantics of Verbal Aspect in Polish," To honor Roman Jakobson, The Hague, Paris, Mouton. 